\title{
ФОРМУВАННЯ ПРОФЕСІЙНОЇ КОМПЕТЕНТНОСТІ МАЙБУТНІХ СТОМАТОЛОГІВ ЗА РЕЗУЛЬТАТАМИ ДОСЛІДЖЕНЬ ВИЩИХ МЕДИЧНИХ НАВЧАЛЬНИХ ЗАКЛАДІВ УКРАЇНИ
}

\author{
Я. А. Кульбашна ${ }^{1}$, Д. С. Аветіков ${ }^{2}$, Я. П. Нагірний ${ }^{3}$, В. В. Ніконов ${ }^{4}$, С. С. Поліщук ${ }^{5}$ \\ ${ }^{1}$ Національний медичний університет ім. О. О. Богомольия, \\ ${ }^{2}$ Украйнська медична стоматологічна академія (м. Полтава), \\ З ДВНЗ “Тернопільський дерэсавний медичний університет імені І. Я. Горбачевського МОЗ Украӥни”, \\ ${ }^{4}$ Харківський національний медичний університет, \\ ${ }^{5}$ Вінницький національний медичний університет ім. М. I. Пирогова
}

\section{FORMING OF PROFESSIONAL COMPETENCE OF FUTURE DENTISTS ON RESEARCH OF UKRAINIAN HIGHER MEDICAL EDUCATIONAL INSTITUTIONS}

\author{
Ya. A. Kulbashna ${ }^{1}$, D. S. Avetikov ${ }^{2}$, Ya. P. Nahirnyi ${ }^{3}$, V. V. Nikonov ${ }^{4}$, S. S. Polishchuk ${ }^{5}$ \\ ${ }^{\prime}$ National Medical University by O. O. Bohomolets, \\ ${ }^{2}$ Ukrainian Medical Stomatological Academy (Poltava), \\ ${ }^{3}$ SHEI "Ternopil State Medical University by I. Ya. Horbachevsky of MPH of Ukraine”, \\ ${ }^{4}$ Kharkiv National Medical University, \\ ${ }^{5}$ Vinnytsia National Medical University by M. I. Pyrohov
}

\begin{abstract}
У статті розкриті окремі аспекти процесу формування професійної компетентності майбутніх стоматологів за результатами дослідження у вищих медичних навчальних закладах України.
\end{abstract}

The article deals with some aspects of the professional competence forming of future dentists according to research results of the Ukrainian Higher Medical Educational Institutions.

Вступ. Реалії сучасних швидкоплинних змін у суспільстві потребують модернізації освітньої галузі. Головною метою реформ стає зміна знаннєвої освітньої парадигми (пряма передача знань викладач студент) на компетентнісну (спрямування випускників на реальне забезпечення практичного упровадження отриманих знань і вмінь, визначення результату освіти у набутих компетентностях і досягнення конкурентоспроможності через самоосвіту, саморозвиток і самовдосконалення). Цьому сприяє широке упровадження компетентнісної моделі, яка у розвинених країнах визнана концептуальною основою професійної підготовки фахівця. Однак, як зазначає В. І. Луговий, європейські фахівці, які уперше запровадили компетентнісний підхід в освіті, наголошують на рекомендаційному характері застосування його положень і необхідності збереження національних особливостей педагогічного процесу. Крім того, се-

( Я. А. Кульбашна, Д. С. Аветіков, Я. П. Нагірний та ін. ред науковців обговорюється необхідність дослідження галузевої специфіки компетентнісного виміру освіти [4].

Вітчизняна вища школа і медична, як іï органічна складова, долучились до Свропейського освітнього простору шляхом приєднання до Болонських угод (2005). На думку науковців Г. Я. Загричука, О. І. Тищенко, проблемам розвитку професійної компетентності присвячені роботи у різних освітніх галузях $[1,6]$. Натомість у медичній виявлені лише поодинокі наукові дослідження окремих аспектів даної проблеми $[2,3,5,7]$. Це диктує необхідність і вищій стоматологічній освіті приєднатись до вивчення та застосування прийнятних положень компетентнісного підходу. Тому в основу підготовки майбутнього стоматолога, відповідно до вимог сьогодення, необхідно покласти розвиток професійної компетентності, забезпечення власної конкурентоспроможності на вітчизняному і міжнародному просторі. Важливим є визначення наявного стану процесу становлення професійної компетентності майбутніх стоматологів в Україні. 
Мета статті - розкрити окремі аспекти процесу формування професійної компетентності майбутніх стоматологів як світоглядного орієнтиру за результатами дослідження у вищих медичних навчальних закладах України (далі - ВМНЗ).

Основна частина. Дослідження проводилось на основі діагностичного анкетування [3] серед вітчизняних і іноземних студентів стоматологічних факультетів (всього 1631 вітчизняних і 456 іноземних студентів 3 - 5 курсів (2013-2014 рр.): Національного медичного університету ім. О. О. Богомольця (НМУ: 408 ос.), Української медичної стоматологічної академії, м. Полтава (УМСА: 324 ос.), Харківського національного медичного університету (ХНМУ: 351 ос.),
Тернопільського державного медичного університету ім. І. Я. Горбачевського (ТДМУ: 273 ос.) та Вінницького національного медичного університету (ВНМУ: 275). У даній роботі аналізуються відповіді лише українських студентів. В результаті виявлено низку важливих питань, які потребують вивчення. Серед них:

1. Визначення глибини розуміння поняття “професійна компетентність" майбутніми стоматологами. Відомо, що остання набуває ефективності за умов оволодіння компетентностями, які рекомендовані єврофахівцями як загальні [8], і потребує виокремлення спеціальних компетентностей, характерних для стоматологічної галузі. Отримані результати представлені у таблиці 1.

Таблиця 1. Самооцінка розуміння майбутніми стоматологами терміна “професійна компетентність”

\begin{tabular}{|c|c|c|c|c|c|c|}
\hline \multirow{3}{*}{ Оцінка сприйняття } & \multicolumn{6}{|c|}{ "Професійна компетентність" } \\
\hline & \multicolumn{2}{|c|}{ HMУ (y \%) } & \multicolumn{2}{|c|}{ YMCA (y \%) } & \multicolumn{2}{|c|}{ XНМУ (y \%) } \\
\hline & 4 курс & 5 курс & 4 курс & 5 курс & 4 курс (219) & 5 курс \\
\hline "Розумію" & 63,5 & 50,6 & 72,1 & 68,8 & 48,1 & 40,1 \\
\hline "Не розумію" & 2,4 & 13,6 & 10,1 & 3,6 & 36,2 & 38,7 \\
\hline "В загальних рисах" & 26,3 & 35,8 & 16,5 & 21,3 & 12,5 & 21,2 \\
\hline $\begin{array}{l}\text { Не сформулювали власне } \\
\text { визначення/але вважають, } \\
\text { що розуміють }\end{array}$ & $37,5 / 64,2$ & $27,1 / 61,2$ & $43,0 / 70,0$ & $29,9 / 57,0$ & $85,1 / 64,2$ & $93,7 / 71,5$ \\
\hline Не відповіли & 7,8 & 0 & 1,3 & 6,3 & 3,2 & - \\
\hline
\end{tabular}

Результати обробки анкет засвідчили, що 2,4 - 38,7 \% студентів не розуміють сутності поняття “професійна компетентність"; 12,5 - 35,8 \% - можуть окреслити лише окремі ознаки. Самостійно сформулювати визначення даного терміна не можуть $27,1-93,7 \%$. Варто зазначити, що з їх числа 57,0 74,1 \% відповіли, що розуміють суть даного поняття. Однак при аналізі відповідей виявилось, що уявлення майбутніх фахівців щодоцьогопоняття досить приблизне і лише мінімально характеризує деякі окремі ознаки (практичні навички, відповідальність за роботу, досвід тощо), а близько половини з них навіть не наближаються до адекватного розуміння. Розбіжність у цифрах, які відображають досліджувані показники серед студентів всередині одного ВМНЗ, незначна, але існує помітна міжвузівська різниця показників. Таке низьке розуміння сучасних базових понять, які характеризують освітні процеси, перешкоджають формуванню світоглядних пріоритетів майбутніх стоматологів.

2. Аналіз мотивів вибору професії як відправного пункту, внутрішнього поштовху, який визначає цілепокладання і напрям руху майбутніх фахівців до становлення професійної компетентності. Отримані дані представлені у таблиці 2.
Результати аналізу отриманих даних свідчать, що, попри віддаленість регіонів і відмінні соціальні умови виховання і розвитку, спостерігається очевидна єдність у мотивації майбутніх стоматологів до навчання у вищих медичних навчальних закладах. Звертають увагу високі показники щодо мотивів допомоги хворим людям, піклування про здоров'я близьких (пункти А, Б) та низькі - щодо вирішення глобальних проблем у науці та практиці (пункти $\Gamma$, Д). Така подібність у поглядах вказує на спільне ціннісне і соціальне підгрунтя для розвитку професійної компетентності майбутніх стоматологів $\mathrm{i}$ уможливлює єдині теоретичні і методологічні підходи у забезпеченні впливу на їх пріоритетну орієнтацію у перспективі.

3. Професійна компетентність, як світоглядний орієнтир для майбутніх стоматологів, може набувати ефективності за умов оволодіння ії важливими складовими, які, на думку європейських експертів, можна об'єднати у групи: фахові, соціальні, методичні і пов'язані з фаховою діяльністю [9]. Результати опитування та пріоритетність компетентностей за ознакою їх значущості представлені у таблиці 3. 
Таблиця 2. Характеристика мотиваційної складової професійної компетентності майбутніх стоматологів

\begin{tabular}{|c|c|c|c|c|c|c|c|c|c|}
\hline \multirow{3}{*}{ Мотив } & \multicolumn{9}{|c|}{ Кількість майбутніх стоматологів (у \%) } \\
\hline & \multicolumn{3}{|c|}{3 курс (248) } & \multicolumn{3}{|c|}{4 курс (276) } & \multicolumn{3}{|c|}{5 курс (324) } \\
\hline & HMY & ТДМУ & BHMY & HMY & ТДМУ & BHMY & HMY & тДМУ & BHMУ \\
\hline $\begin{array}{l}\text { А. Допомагати хворим } \\
\text { людям }\end{array}$ & 75,5 & 58,2 & 60,4 & 62,6 & 63,4 & 64,2 & 60,3 & 68,2 & 68,3 \\
\hline $\begin{array}{l}\text { Б. Піклуватися про } \\
\text { здоров'я близьких }\end{array}$ & 60,0 & 43,3 & 55,0 & 56,0 & 56,3 & 63,8 & 62,8 & 50,0 & 54,2 \\
\hline $\begin{array}{l}\text { В. Піклуватися про своє } \\
\text { здоров'я }\end{array}$ & 28,8 & 27,0 & 33,0 & 35,1 & 38,4 & 59,1 & 37,8 & 26,2 & 40,8 \\
\hline $\begin{array}{l}\text { Г. Вирішувати глобальні } \\
\text { наукові проблеми }\end{array}$ & 11,1 & 6,0 & 7,7 & 12,0 & 5,4 & 7,1 & 6,0 & 5,0 & 15,0 \\
\hline $\begin{array}{l}\text { Д. Вирішувати глобальні } \\
\text { практичні проблеми }\end{array}$ & 14,4 & 7,5 & 15,4 & 21,9 & 10,0 & 11,5 & 11,2 & 6,0 & 17,0 \\
\hline $\begin{array}{l}\text { Є. Престижність } \\
\text { спеціальності лікаря }\end{array}$ & 50,0 & 46,3 & 55,0 & 45,1 & 54,0 & 40,9 & 46,5 & 50,0 & 55,0 \\
\hline $\begin{array}{l}\text { Ж. Матеріальна } \\
\text { зацікавленість }\end{array}$ & 42,2 & 34,3 & 46,2 & 46,1 & 53,0 & 42,8 & 48,2 & 47,0 & 50,0 \\
\hline 3. Сімейні традиції & 23,3 & 19,4 & 27,5 & 32,9 & 21,4 & 24,6 & 30,1 & 16,0 & 24,2 \\
\hline $\begin{array}{l}\text { И. Розгортання власного } \\
\text { бізнесу }\end{array}$ & 35,5 & 42,0 & 41,0 & 40,7 & 37,0 & 33,1 & 35,3 & 34,1 & 34,2 \\
\hline І. Еміграція & 11,1 & 15,0 & 20,0 & 25,2 & 17,0 & 22,8 & 12,0 & 9,1 & 20,8 \\
\hline $\begin{array}{l}\text { Й. Контрактна робота за } \\
\text { кордоном }\end{array}$ & 16,6 & 7,5 & 15,4 & 15,3 & 18,0 & 18,0 & 7,7 & 5,0 & 21,7 \\
\hline $\begin{array}{l}\text { К. Управлінська робота в } \\
\text { органах охорони здоров'я }\end{array}$ & 5,6 & 7,5 & 3,3 & 55,6 & 5,0 & 6,9 & 1,7 & 10,2 & 4,2 \\
\hline
\end{tabular}

Таблиця 3. Характеристика майбутніми стоматологами компетентностей за ознакою їх значущості

\begin{tabular}{|l|c|c|c|c|c|c|}
\hline \multirow{2}{*}{ Компетентності } & \multicolumn{3}{|c|}{ курс (у \%) } & \multicolumn{3}{c|}{5 курс (у \%) } \\
\cline { 2 - 7 } & HМУ & УМСА & ХНМУ & HМУ & УМСА & ХНМУ \\
\hline Фахові & 53,0 & 45,3 & 51,1 & 67,8 & 51,5 & 37,1 \\
\hline Пов'язані з профдіяльністю & 25,3 & 36,0 & 11,1 & 37,0 & 24,4 & 16,6 \\
\hline Соціальні & 17,1 & 12,0 & 32,8 & 20,8 & 16,3 & 35,6 \\
\hline Методичні & 4,0 & 2,1 & 15,3 & 7,0 & 4,0 & 15,1 \\
\hline Не відповіли & 3,0 & 5,3 & 3,2 & 3,0 & 4,0 & 1,5 \\
\hline
\end{tabular}

Аналіз даних таблиці 3 засвідчив очевидну перевагу фахових (45,3-67,8 \%) і пов'язаних з фаховими компетентностей $(24,4-37 \%)$, нижчий рейтинг соціальних $(12,0-35,6 \%)$ і мінімальний - методичних $(2,1-15,1 \%)$ компетентностей. Не змогли дати відповідь на запитання 3,0-5,3 \% студентів. Поряд із цим, уточнимо, що всі вищезазначені компетентності були відзначені майбутніми стоматологами як актуальні. Отримані результати вказують на відсутність, у більшості студентів, усвідомлення труднощів власної соціалізації у майбутній професійній діяльності й особистому житті, а також на недостатню увагу до даної проблеми з боку викладачів. Звертає увагу одностайність вибору і розподілу значущості пред- ставлених компетентностей представниками різних регіонів. Очевидно, що майбутні стоматологи недооцінюють важливість формування усього комплексу компетентностей. Це пов'язано, вірогідно, з низьким розумінням їх сутності і може завадити успіху у майбутній професійній діяльності.

4. Для об'єктивного розуміння стану процесу формування професійної компетентності важливим $€$ визначення думки майбутніх стоматологів щодо оволодіння необхідними компетентностями у ВМНЗ. Результати дослідження представлені у таблиці 4.

Аналіз таблиці 4 засвідчив, що, за даними самооцінки майбутніх стоматологів, менше половини з них $(25,2-46,9 \%)$ вважає, що набуває необхідних компе- 
тентностей у процесі навчання, а 13,6 - 61,1% вважає, що лише частково. Цікавою видається картина показників негативної оцінки, яка вказує, що значна частина (до 38,6 \%) закінчує ВМНЗ без оволодіння необхідними компетентностями. Така ситуація по- требує ретельного аналізу викладацькими колективами і корекції.

Причини, які, на думку студентів, перешкоджають процесу формування професійної компетентності, наведені у таблиці 5.

Таблиця 4. Характеристика рівня оволодіння майбутніми стоматологами компетентностями

\begin{tabular}{|l|c|c|c|c|c|c|}
\hline \multirow{2}{*}{ Компетентності } & \multicolumn{3}{|c|}{4 курс } & \multicolumn{3}{c|}{5 курс } \\
\cline { 2 - 7 } & НМУ & УМСА & ХНМУ & НМУ & УМСА & ХНМУ \\
\hline Набувають & 28,1 & 39,2 & 40,0 & 25,2 & 34,7 & 46,9 \\
\hline Не набувають & 6,7 & 11,5 & 30,2 & 9,6 & 6,0 & 38,6 \\
\hline Частково & 61,1 & 39,2 & 26,5 & 63,9 & 53,1 & 13,6 \\
\hline Не відповіли & 4,1 & 10,1 & 3,3 & 1,3 & 6,2 & 0,9 \\
\hline
\end{tabular}

Таблиця 5. Характеристика основних причин, які перешкоджають формуванню професійної компетентності майбутніх стоматологів

\begin{tabular}{|l|c|c|c|c|c|c|}
\hline \multirow{2}{*}{ Причина } & \multicolumn{3}{|c|}{4 курс } & \multicolumn{3}{c|}{5 курс } \\
\cline { 2 - 7 } & НМУ & УМСА & ХНМУ & HМУ & УМСА & ХНМУ \\
\hline Власна пасивність & 23,6 & 27,8 & 18,6 & 22,6 & 44,8 & 23,4 \\
\hline Некомпетентність викладачів & 44,4 & 62,0 & 41,8 & 55,2 & 29,7 & 37,8 \\
\hline $\begin{array}{l}\text { Перенавантаження навчальних } \\
\text { програм }\end{array}$ & 84,2 & 53,2 & 29,7 & 53,5 & 45,3 & 27,2 \\
\hline Інші причини & 14,1 & 10,1 & 9,3 & 15,6 & 16,1 & - \\
\hline Не відповіли & 5,0 & 13,4 & 3,2 & - & 17,2 & 12,6 \\
\hline
\end{tabular}

Отримані дані свідчать, що основною перешкодою на шляху становлення професійної компетентності $є$ перенавантаження навчальних програм (84,2-27,2 \%), недостатня підготовленість викладачів (29,7-84,2 \%). Поряд 3 цим, близько третини студентів відзначають власну пасивність. Важливо проаналізувати глибше саме цю складову, оскільки на неї вказало близько третини опитаних $(18,6-27,8 \%)$.
5. Професійна компетентність реалізується у фаховій діяльності, а від рівня іiї сформованості безпосередньо залежить конкурентоспроможність фахівця на ринку праці. Оцінка майбутніми стоматологами рівня власної конкурентноспроможності представлена у таблиці 6.

Таблиця 6. Самооцінка майбутніх фахівців рівня власної конкурентоспроможності

\begin{tabular}{|c|c|c|c|c|c|c|}
\hline \multirow{3}{*}{ Рівень конкурентоспроможності } & \multicolumn{6}{|c|}{ Кількість осіб (у \%) } \\
\hline & \multicolumn{2}{|c|}{ HMY } & \multicolumn{2}{|c|}{ УМСA } & \multicolumn{2}{|c|}{ ХНМУ } \\
\hline & 4 курс & 5 курс & 4 курс & 5 курс & 4 курс & 5 курс \\
\hline "Конкурентоспроможний” & 20,0 & 26,5 & 26,5 & 31,7 & 41,4 & 39,4 \\
\hline “Ще ні” & 70,8 & 63,9 & 67,5 & 62,0 & 42,7 & 40,1 \\
\hline "Неконкурентоспроможний" & 6,2 & 9,6 & 3,8 & 5,3 & 11,6 & 18,1 \\
\hline Не відповіли & 2,8 & $\begin{array}{ll}- \\
-\end{array}$ & 2,2 & 1,0 & 3,2 & 2,2 \\
\hline
\end{tabular}

Отримані результати свідчать, що високо оцінили власний рівень конкурентоспроможності лише 26,539,4 \% випускників, тобто близько третини опитаних; студенти 5 курсу виявилися менше упевненими у своїй конкурентоспроможності, що може вказувати, очевидно, на більшу самовимогливість у визначенні кри- теріїв оцінки (20,0-41,4\%); більшість студентів (62,070,8 \%) вказує лише на початковий рівень. Цілком зрозуміло, що під час навчання у ВМНЗ неможливо підготувати повністю конкурентоспроможного фахівця, але при усуненні виявлених суттєвих перешкод його рівень може значно підвищитись. 
Висновки. Таким чином, дослідження розвитку професійної компетентності майбутніх стоматологів виявило недостатній рівень його розуміння і сприйняття, значущості складових та рівня становлення у ВМНЗ. Висвітлені основні причини, які перешкоджають успішності процесу формування професійної компетентності (недостатня компетентність викладачів, перенавантаженість програм тощо). Відзначена подібність мотиваційної складової, що вказує на спільні ціннісні погляди студентів. Отримані результати вказують на необхідність цілеспрямування випускників на забезпечення власної конкурентоспро-

\section{Література}

1. Загричук Г. Я. Підготовка фахівців у вищих навчальних закладах України в сучасних умовах на основі компетентнісного підходу / Г. Я. Загричук, В. П. Марценюк, І. Р. Мисула // Медична освіта. - 2013. - № 1. - С. 11.

2. Кліш Г. І. Професійна компетентність як мета підготовки лікарів у медичному університеті Відня [Електронний pecypc] / Г. І. Кліщ. - Режим доступу: http:// virtkafedra.ucoz.ua/el_gurnal/pages/vyp8/Klish.pdf

3. Кульбашна Я. А. Анкета дослідження показників формування професійної компетентності майбутніх стоматологів / Я. А. Кульбашна // Свідоцтво про реєстрацію авторського права на твір. - № 50865 $;$; 22.08.2013.

4. Луговий В. І. Освіта, навчання, інформація, компетентність: канонізація понять // Історико-педагогічні студії: науковий часопис / гол. ред. Н. Н. Демяненко. - К. : Вид. НПУ імені М. П. Драгоманова, 2011.-Вип. 5. - С. 11-16. можності, підвищення рівня адаптації у міжнародному середовищі. Результати дослідження уможливлюють для науково-педагогічних колективів ВМН3 розробку єдиних підходів до організації процесу формування професійної компетентності майбутніх стоматологів. Для обговорення і вирішення нагальних проблем доцільним є створення Асоціації стоматологічної освіти України. Подальші дослідження варто проводити у напрямі удосконалення традиційних $\mathrm{i}$ упровадження інноваційних форм навчання, розробки структурно-компонентної моделі досліджуваного процесу та його міжнародних аспектів.

5. Мруга М. Р. Структурно-функціональна модель професійної компетентності майбутнього лікаря як основа діагностування його фахових якостей : дис. ... канд. пед. наук : 13.00.04 / Мруга Марина Рашидівна. -К., 2006. - 251 с.

6. Тищенко О. І. Загальнонаукові засади дослідження поняття професійної компетентності [Електронний ресурс]/ O. I. Тищенко. - Режим доступу: http:/virtkafedra.ucoz.ua/ el_gurnal/pages/vyp10/tishenko.pdf

7. Chambers D. W. Competencies (a new view of becoming a dentist) / D. W. Chambers // Journal of Dental Education. 1994. - Vol. 58. - P. 342-345.

8. Turning Education Structure in Europe . - URL: http:// turning.unideusto.org

9. Lenske W.,Werner D. Globalisierung und internationale Berufskompetenz URL:http:/www.nabibb.de/fileadmin/ user_upload/Dokumente/LDV/mob/df/2011_ldv_mob_df_ spIII_schaubild.pdf 